\title{
Sundanese Dialect in Sinar Resmi Traditional Village in Cisolok District, Sukabumi Regency: Phonological Perspective
}

\author{
Husni Thamrin, \& Retty Isnendes \\ Program Studi Linguistik, Universitas Pendidikan Indonesia \\ husnithamrin@unpas.ac.id; retty.isnendes@upi.edu
}

\begin{abstract}
How to cite (in APA Style): Thamrin, H. \& Isnendes, R. (2019). Sundanese Dialect in Sinar Resmi Traditional Village in Cisolok District, Sukabumi Regency: Phonological Perspective. Jurnal Pendidikan Bahasa dan Sastra, 20(1), 1-15. DOI: https://doi.org/10.17509/bs_jpbsp.v20i1.25965
\end{abstract}

Article History: Received (15 December 2019); Revised (5 March 2020 ); Accepted (1 April 2020) Journal homepage: http:// ejournal.upi.edu./index.php/BS_JPBSP

\begin{abstract}
The main purpose of this study is to find out the similarities and differences in the form of speaking dialect intonation of Sirna Resmi tradisional society of Sukabumi Regency which is spoken by parents and young people. This study is conducted qualitatively with identification and classification in the form of Sundanese intonation of conversation dialect. Participants are two people with the age level of young (36 years old) and parents (69 years old). Data is collected by interview and record notes. Analysis of conversational dialect data is based on phonological theory of intonance referred to Katamba (1996). The first data is found with a number of intonations of conversational dialects from young people (36 years old) totaling 30 conversation sentences. From the data found three types of categories, namely; First intonation of downdrift tones is found in 2 types. Second, the tone of the downstep is found in 10 types. Third, the tone upstep is found in 18 types. In the second data, it was found that conversational dialect sentences of parents (69 years) amounted to 30 sentences of parents as elders in the Sinar Resmi village indigenous people. From the data that found three types of categories, namely; 1) Intonation of downdrift tones found 10 types. 2) Intonation of downstep tone found 11 types. 3) Intonation of upstep tones found 9 types.

Keywords: dialect; phonology; downdrift intonation; downstep intonation; upstep intonation

\section{Dialek Bahasa Sunda di Kampung Adat Sinar Resmi Kecamatan Cisolok Kabupaten Sukabumi (Perspektif Fonologi)}

\begin{abstract}
Abstrak: Tujuan utama dari penelitian ini adalah untuk mengetahui persamaan dan perbedaan bentuk intonasi dialek percakapan masyarakat adat kampung Sirna Resmi Kabupaten Sukabumi yang dituturkan oleh kalangan orang tua dan anak muda. Studi ini dilakukan secara kualitatif dengan identifikasi dan klasifikasi pada bentuk intonasi dialek percakapan bahasa Sunda. Partisipan yang dilibatkan dalam wawancara sebanyak dua orang dengan tingkatan usia kalangan muda (36 Ttahun) dan orang tua (69 tahun). Data dikumpulkan dengan cara wawancara dan rekam catat. Analisis data dialek percakapan berpedoman pada teori fonologi, khususnya irama/intonasi berbasis Katamba (1996). Ditemukan data pertama dengan sejumlah intonasi kalimat dialek percakapan dari kalangan muda (36 tahun) berjumlah 30 kalimat percakapan Dari data tersebut ditemukan tiga jenis kategori yaitu; Pertama, Intonasi nada downdrift ditemukan 2 jenis. Kedua, Intonasi nada downstep ditemukan 10 jenis. Ketiga, Intonasi nada upstep ditemukan 18 jenis. Pada data kedua, ditemukan kalimat dialek percakapan orang tua (69 tahun) berjumlah 30 kalimat orang tua sebagai sesepuh di masyarakat adat kampung Sinar Resmi. Dari data tersebut ditemukan tiga jenis kategori yaitu; 1) Intonasi nada downdrift ditemukan 10 jenis. 2) Intonasi nada downstep ditemukan 11 jenis. 3) Intonasi nada upstep ditemukan 9 jenis.
\end{abstract}

Kata kunci: dialek; fonologi; intonasi downdrift, intonasi downstep; intonasi upstep 


\section{INTRODUCTION}

Dialectology is a branch of linguistics that study variations in language by treating it as a unified whole structure (Kridalaksana, 2001 a, p. 42). It can be understood that dialect differences can occur and be felt directly in the field of phonology, and usually dialect or language users are not aware of these differences. As some examples the word of careme with cereme. 'Fruit (tree) cerme (Phyllanthus cidus Skells, Cicca disticha Linn.)', 'gudang' is derived of the word 'kudang' 'gudang', jendela, gandela or janela 'jendela', mandadaki with manakak '(name \& similar) perdu (Because of camara Linn, Lantana aculat '; Linn.)' in Sundanese (BS). From these examples it appears that phonetic differences can occur in vowels or consonants (Ayatrohaedi, 1979, p.4).

Dialect is also often regarded as the correct norm and is considered a standard language (Chamber \& Trudgil, 1998, p.3). The origin of the term dialect which is a dialect equivalent is more commonly used in linguistic conversation (Ayatrohaedi, 1979, p.1). Dialectology is a branch of linguistics that studies language variations by treating them with intact structures (Kridalaksana, 2001b, p. 42). Dialect is a linguistic branch dialect which aimed at analyzing all the linguistic symptoms in detail to be displayed based on factual linguistic maps so that the geographic dialect as a study has the same systematic as regional dialects (Crystal, 1989, p.26). However, on the contrary, the social dialect is the variety of languages used by certain groups of people in the presence of distinctive characteristics specifically from outside community groups (Zulaeha, 2010, p.29). According to Nababan (1993) divides language variations into four, namely as follows: (1). Variety of dialects. (2). The Sosiolek variety (3). The variety of functions is a third group of languages related to the language situation. (4). The Kronolek variety. It is clear that the dialect has a great variety of varieties ranging from the widest of regional dialects, social societies, situations and functions to the use of the dialect itself.
According to Pennington (2007, p.1) phonology is the study of how sound is arranged in its use in a language system). Next, Davenport and Hannah (2005, p.2-3) said that phonology is the study of speech sounds arranged in an individual language system. Whereas Clark \& Collin (1995, p.1) explains that phonology is a science that focuses on various forms of speech produced by humans by listening to these types of utterances. A characteristic system of language sounds that specifically distinguishes one language from another so that the different arrangement of sound systems has its own sign of meaning (McMahon, 2016, p.2). Phonology is the study of the structure system of sound in language (Odden, 2005, p.2). Then Kugler (2009, p.1) says that there is a dialect at each level of representation that is viewed from a phonological point of view. It can be concluded that phonology is the study of sound structures arranged systematically starting from vowel phonemes and consonants into units of words so that they form a unit of speech that has meaning.

"Phoneme is the smallest sound unit capable of showing contrast of meaning, for example in Indonesian $/ \mathrm{h} /$ is a phoneme because it distinguishes the meaning of the word must and current; /b/ and /p/ are two different phonemes due to /bara/ and /para/ different meanings" (KBBI, 2001, p.319). Based on Pateda (1988, p. 59) explains that phoneme is a sound that has a function to distinguish the meaning of the word from other words, also called all sounds that can distinguish meaning. Whereas Alwi (2003, p.26) explains that phonemes are sounds of language which have at least differences in form and meaning. According to Samsuri (1991, p.17) says that phonemes are utterances that can be made by human utensils in the form of countless sounds. While Chaer (2003, p.132) explains that in certain languages there are phoneme changes that change the phoneme's identity into another phoneme. "Morpheme is the smallest grammatical unit that has meaning" (Chaer, 2003, p.146). Based on Yule (1986, p.60); "The definition of a 
minimum unit of meaning or grammatical function." That the morpheme is the smallest part that has grammatical meaning and function. Samsuri (1991, p.15) says that morphemes can be expressed as the smallest unit that has its own meaning. "A linguistic form which bears no partial phonetic semantic resemblance to any other form, is a simple form or a morpheme" Bloomfield (in Parera 1994, p.14). It is quite clear that the morpheme is the smallest part that has special grammatical meaning.

"Word is the smallest free form that has phonological unity and grammatical unity which contains an understanding" (Putrayasa, 2008, p.44). In line with that, Ramlan (1997, p. 7) mentions words as the least free form or in other words every free form is a word. Kridaklaksana (2001, p.98) states that words are morphemes or morpheme combinations which are considered by the discussion as the smallest units which can be said as free forms. From the linguist experts we can conclude that the word can be seen from the nature of freedom and has one meaning

Intonation is a high and low tone in a sentence that has an emphasis on a particular word or vocabulary in a sentence. When the speaker produces a sentence in the form of speech, the sequence of word structures can be categorized in the form of intonation phrases (Gut, 2009, p.3). Whereas, according to Gordon (2016, p.2015) 'Intonation is used to communicate higher levels of information not associated with morphemes' Intonation is used for higher information communication where there is no link between words and morpheme. Furthermore, De lacy (2007, p.254) explains that intonation refers to the structure of variation in high and low tones which cannot be compared with the distribution of different types of vocabulary. Whereas Roach (1998 p. 133) suggests that the intonation of a tone is of course produced by the vibration of the vocal cords and the tone intonation has an important role to play on the high and low speech spoken by someone. Also explained by Lodge (2009, p.15), that the occurrence of high low-pressure tones when viewed from a phonological point of view, is located in the human organs as a source of sound which has similarities and differences to the utterances in general in the form of common language what is spoken is very much determined by the particular form of language structure. The form of intonation is represented linearly by a series of segmental tones automatically, then equated with certain syllables and phrases to indicate the emergence of a strong association between speech words and prosody groupings, i.e., metrics and prosody's speech structure (Ah Jun 2006, p. 2). Intonation in Indonesian is a hierarchical structure, no longer a linear structure (Halim, 1984: 80). In general, he introduced four distinguishing components in the hierarchical structure of Indonesian intonation, namely (a) intonation pattern, (b) pause group, (c) contour, and (d) intonation phoneme.

Intonation is the most important subject of analysis at the level of sentence grammar (Katamba, 1996, p. 204). The syllables are Inti (NUCLEUS) or tone syllables (TONIC SYLLABLE). Syllable tones are usually preceded by the first head. The head is a part of the tone unit that extends from the first syllable that gets the syllable pressure before the syllable (tonic syllable). Optionally, the head can be preceded by PRE-HEAD. This pre head consists of every unstressed syllable that appears in front of the first syllable. Again, optionally, the syllable tone can be followed by TAIL (the end of the word). The tail contains any syllable (which may or may not be emphasized) following the syllable tone. The intonation formula described by Katamba is like the example below; 
Jurnal Pendidikan Bahasa dan Sastra, Volume 20, Nomor 1, April 2020, pp. 1 - 15

key: $P h=$ pre-head; $H=$ head; $T s=$ tonic syllable; $T$ $=$ tail

$\|_{P h}$ He will $|\underset{H}{\text { phone you when }}| \begin{gathered}\text { all } \\ T S\end{gathered} \mid$ the children are back. $\|$

From the explanation of the sentence above, it can be understood that 'He will' = Pre Head which describes each unstressed syllable that appears in front of the first syllable. 'Phone you when' = Head is a part of the tone unit that extends from the first syllable that gets syllable pressure. 'All' = sylable tone is a tone syllable. Children the children are back ' $=$ Tone Sylable which is the final syllable that usually does not have intonation of the sound and there is no pressure.

Then Katamba (1996, p. 206-208) has explained that the sound intonation can be in the form of 3 rhythm tones. First the rhythm of the DOWNDRIFT tone is the tone of the language which tends to rise later rather slowly and becomes low, like the shape of the terrace (terracing) in the example image 1 below;

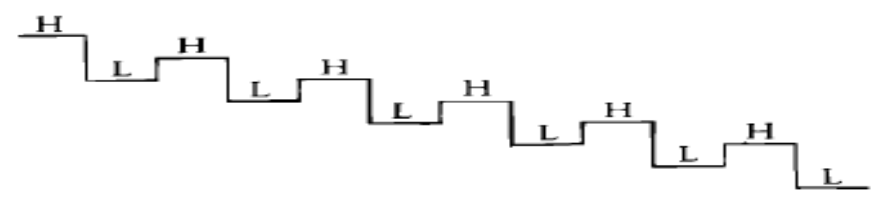

Figure 1. the rhythm of the DOWNDRIFT tone

Second, the rhythm of the DOWNSTEP tone is the tone used to explain the lowpitch situation to high and automatically not motivated by a low tone then the tone slowly rises again, as in the example picture 2 below;

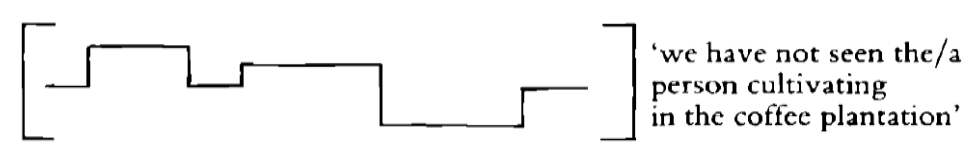

Figure 2. the rhythm of the DOWNSTEP tone

Third, the UPSTEP tone rhythm is the opposite of the downstep tone, the moving tone is high so phonetically the tone is slowly higher than the word that preceded it, as seen in example 3 below;

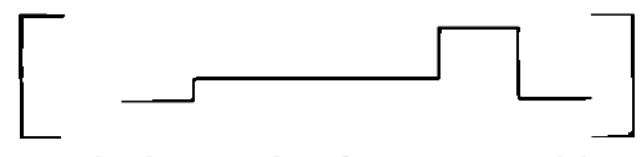

'the boys who do not want it'

Figure 3. the UPSTEP tone rhythm

The explanation of the tone of tone flow that has been stated by Katamba, it can be understood that there are many tone intonations that occur in all directions either downward or upward. But the intonation of the tone rhythm is more likely to be in three strands, namely downdrift, downstep, and upstep.

In addition to the phonetic level, the dialect can also be clearly analyzed from the elements of stress (rhythm) and tone rhythm or intonance of speech 
sounds to speakers of a language. In general, the rhythm of language sounds from high pitch to low pitch (Katamba, 1996, p.205). It can be understood that the dialect of a language that exists in every society has a lot of language variations, such as the short-length of the phoneme or the shape of the letters both the vowels and consonants in the pronunciation.

Related to the study of dialect language, there are several previous studies that examined the dialect of the Linguistic perspective, for example (Arifin, 2017) has conducted research on. "Priangan Dialect Sundanese Language" with a focus on analysis of Pragmatic studies. (Waridah, 2015) has conducted research, "The Use of Language and Language Variation in Language and Culture" with the focus of its analysis from a cultural and sociolinguistic perspective. (Makhtar, 2018) has carried out research, "The Effect of Kelantan Dialect on Temiar Language: One Structural Phonology analysis" with the focus of his analysis of phonetic transcription using the IPA Chart.

So far, there has been no dialectrelated research in terms of the phonological perspective on intonance (rhythm) in the Sundanese dialect of Sukabumi, precisely in the Kasepuhan Sinar Resmi community, Cisolok district, Sukabumi regency, West Java. The focus of this study is only on dialect analysis in the form of words and conversational sentences spoken specifically by the Kasepuhan community of Sinar Resmi is viewed from the perspective of the phonological process.

\section{METHOD}

This study uses qualitative and quantitative descriptive procedures that aim to find the accuracy of the language data as it is. In this case the data source as the object to be examined must be true in its existence, there is no addition, reduction and manipulation of data in the normal form of describing a number of data. It is clear that qualitative research is a study to determine the validity of the description of linguistic data that is natural as it is. Therefore this study was conducted qualitatively through the process of identifying and classifying qualitatively based on phonological theory. The qualitative element of this study lies primarily in the identification and classification of forms of rhythm /intonance. The descriptive quantitative element of this study is related to tracing trends in the emergence of types of phoneme transcription.

The research site was in the traditional village of Sinar Resmi Village, Cisolok District, Sukabumi, West Java. The selection of this area was chosen because the indigenous people could maintain local culture and language. Participants involved in the interview were two people with adolescents and parents, namely Abah Amil (69 years) and Erik (36 years). The selection of these participants is to find out the dialect / intonance of language dialects at that age level.

\section{RESULTS AND DISCUSSIONS}

In this section presents the findings of various forms of word intonation rhythms in the dialect of conversation, most of which are varied intonation rhythms in the sentences spoken by participants. In addition, the form of the intonation rhythm will be discussed orthographically, namely the process that takes place in the flow of the form of intonation. In this study two parts will be explained, which consist of (1) description of data in general, (2) discussion of intonation rhythm analysis in the dialect of conversation.

The data of this study included 60 conversational dialect sentences from two respondents. The overall number of categories of downdrift tone intonation is 12 types of intonation. Then the tone tone of the downstep is 21 intonations. Finally, Upstep tone tone numbered 17.

The general description of data 1 can be seen in Figure 1 below 
Jurnal Pendidikan Bahasa dan Sastra, Volume 20, Nomor 1, April 2020, pp. 1 - 15

Data 1 (Erik 36 years old)

No Conversational Dialect Sentence

Form of intonation Rhythm

(DOWNDRIFT, DOWNSTEP, and UPSTEP)

1. Ai Pengujung mah upami anyar, eta wae, naon nya.

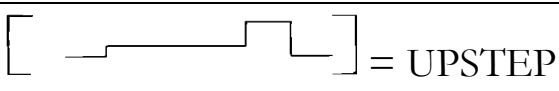

2. ai tamu mah ten kedah di ieu sih.....

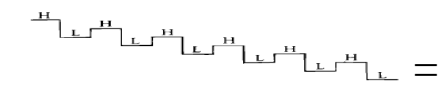

DOWNDRIFT

3. Upami lamun urang teh ulah ka leuwihan teuing wae gitu, leres ngke sugesti da.

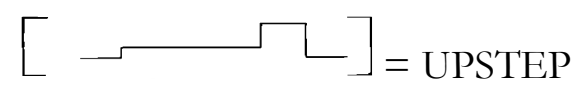

4. Kadie mah asal niatna baik mah, alhamdullilah

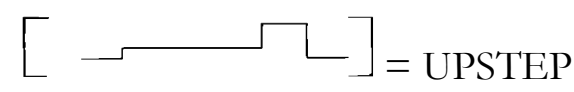

5. Niat bener lah kitu, da upami niat ieu mah ti jalan keneh ntos aman-aman.

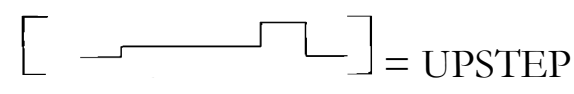

6. $\boldsymbol{A} \boldsymbol{h}$ ai tamu mah da engke ge katingalien iye gitu. . ku tamu mah, teu nu ieu,.teu nи ieu nu eta.

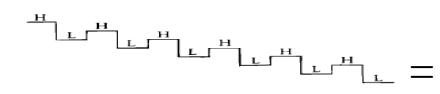

DOWNDRIFT

7. Ai leres mah kedah nu inget kitu, kanggo ka istri, nganggo kain aya kitu

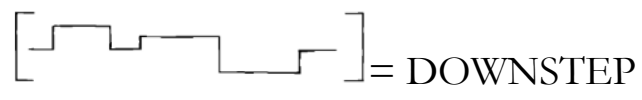

8. Upami urang teh upami tamu pan...iye ab eta ge nyadar nyalira engkin engke cacandakkeunna

9. Upami didieu mah nu paling di ieu kedah tina pare tea
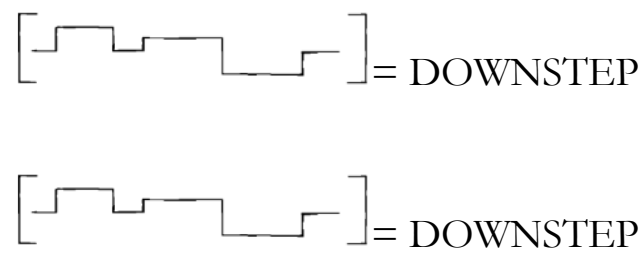

10. Pare teh teu kenging dijual belikeun, husus di konsumsi

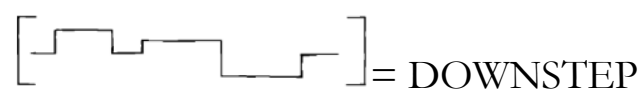

11. Jadi kan parenage panen sataun sakali

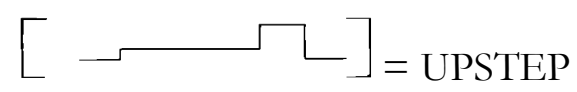

12. Jadi filosofina upami terang sataun sekali..filosopina kieu, jadi moal aya jalma nu birup dua kali

13. Siga ieu bae, nu ngandung kitu pasti sataun sakali, anu ngandung, nu hamil nu ngalabirkeun..moal dua kali.pan sataun

14. Soalna ngajaga kasaimbangeun tanehna, sataun sakali
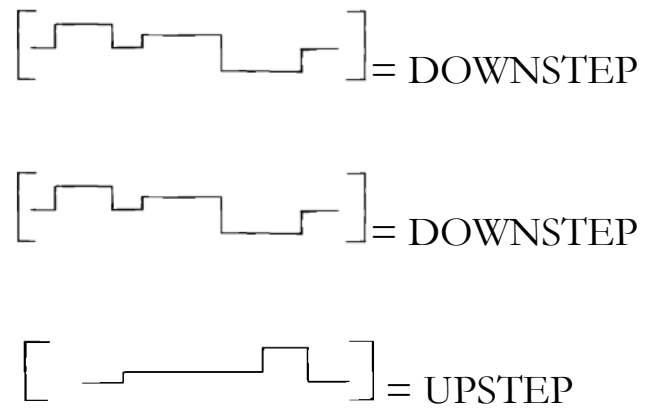

15. Malahan dukatah sawah nu dibandap mah tara dipupuk

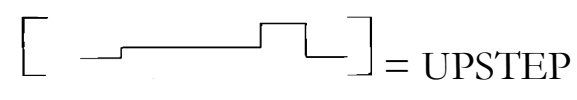

16. Lamun bade melak deui, angkat silaukna teb

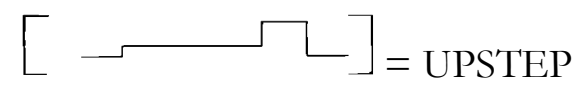

17. Tere ka ageung lankna teh

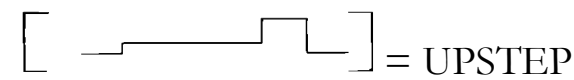


Thamrin, \& Isnendes, Sundanese dialect in Sinar Resmi traditional village in Solok district ...

18. Gerenyih laukna teh

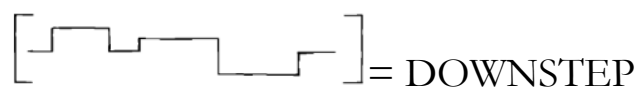

19. Aya Emas, aya Nila

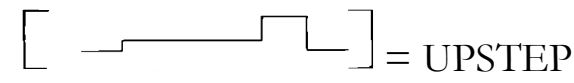

20. Abah tah seer laukna

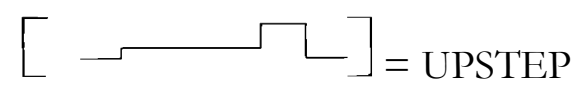

21. Soalna dina Lumbung padi oge bisa nyampe puluban taun.

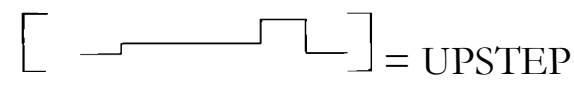

22. Nganggo pupukna teh seperti iye wae upami urang mendak suka dileuweung aya laleuran

23. Eta mah mangga tiasa di konsumsi kn urang
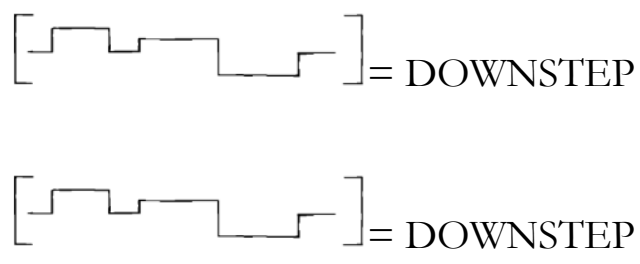

24. Ayeuna wae eta di supermarket, bararesih

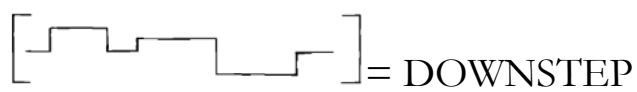

25. Upami kue-kue ini mah moal lami tahanna

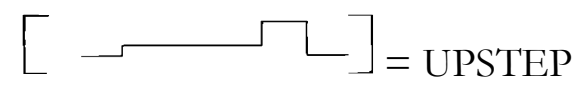

26. Da upami misalkan panen taun ayeuna

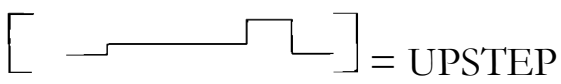

27. Anu di emam na mah tabun ka pengker

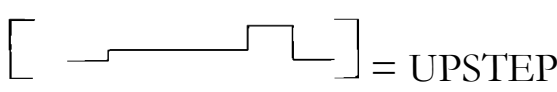

28. Ngke dina sangu pare anyar

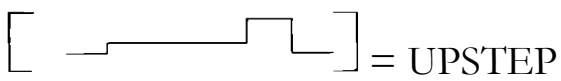

29. Ari melakna ku abah heula

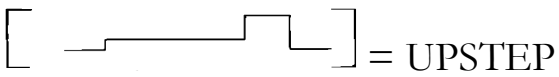

30. Terus bade ageung, naon kembangan, salametan deui
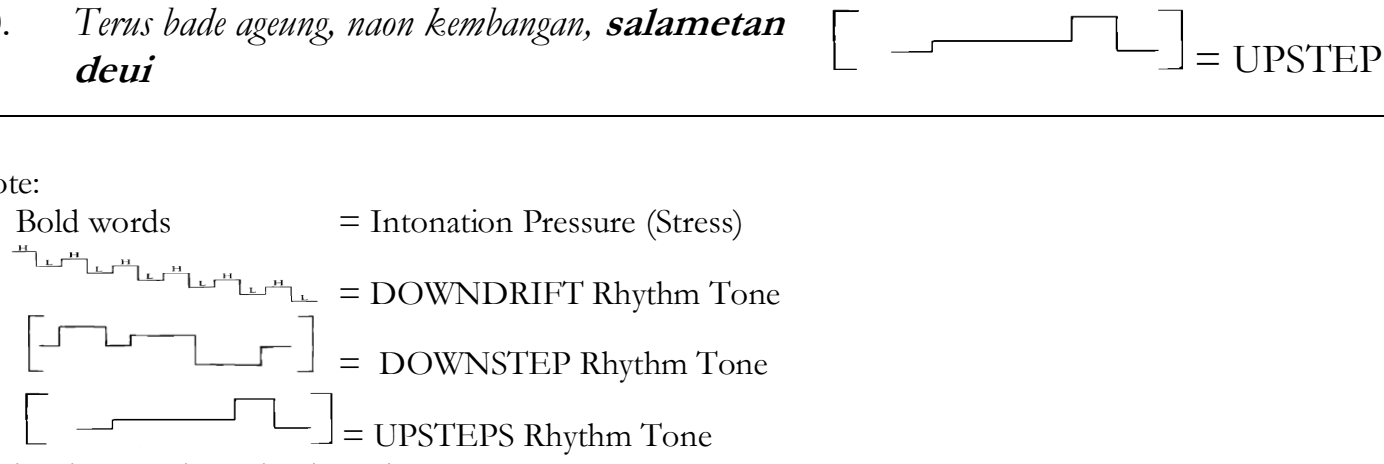

Voice intonation rhythm data 1:
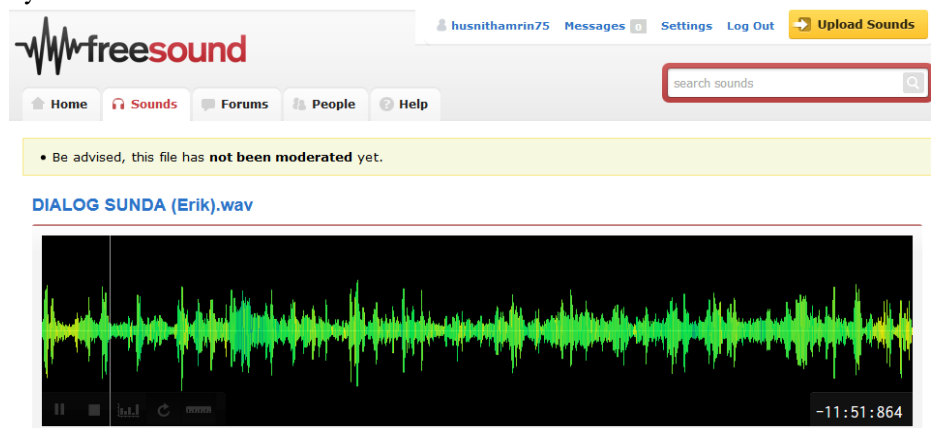

husnithamrin75 
The description of the research data above found a number of intonations of conversation dialect sentences from Erik (36 years) totaling 30 conversational sentences representing the teenagers in the millennial era in the Sinar Resmi village indigenous people. The data found three types of categories, namely; First, the DOWNDRIFT Intonation tone is found in 2 types. Second, the tone of DOWNSTEP found 10 types. Third, the tone of UPSTEP is found in 18 types. It is clear that the intonation wave of sounds that tone tone is more likely to start from lower then end up high so that the appearance of upstep tone tone is more dominant in data 1 with respondents among adolescents.

- Data Analysis 1 (Erik 36 years)

Data 1.6:

$\boldsymbol{A h}$ ai tamu mah da engke ge katingalien ieu gitu. . ku tати mah, tеи пи ieu,.tеu пи ieu nu eta.

In the example data 1.6 above is an intonation of downdrift tones. In the word ' $\boldsymbol{A} \boldsymbol{h}$ ' the tone tone tends to be high, then it slows down slowly to the word 'ai guest' and rises up again to the word 'mah', drops lower again to the word 'da engke ge katingalien', rises again to the word 'ieu' decreases again in the word gitu..ku tamu

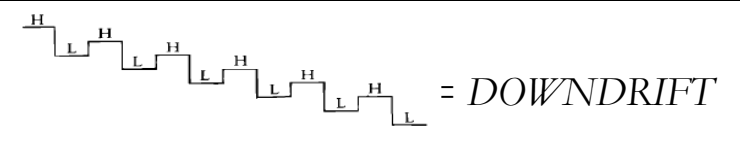

'rises again in the word ' $m a \boldsymbol{h}^{\prime}$ ' decreasing again in the word 'teu nu' rising again in the word 'ieu' decreases again in the word 'ten $n u^{\prime}$ rising again in the word 'ieu' and ends down lower again in the word ' $n u$ eta.' So that the tone is shaped like a descending terrace of stairs.

Data 1.7: $[\neg \square-\neg]=$ DOWNSTEP Rhythm Tone

Ai leres mah kedah nu inget kitu, kanggo ka istri, nganggo kain aya kitu

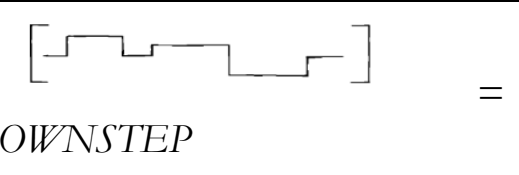

down again to the word 'kitu, kanggo istri, nganggo' rising again to the word 'kain' decreases again in the word 'aya' slowly rising again 'ieu' so that the tone grooves are shaped like a corrugated terrace

\section{DOWNSTEP}

In the sample data 1.7 above is the tone of the downstep tone. In the word 'Ai leres' the tone is low. Then it was rather slow to go high on the word ' $m a^{\prime} \boldsymbol{h}^{\prime}$ and slowly the tone returned low to the word 'kedah $n u^{\prime}$ slowly rising again on the word 'inget'

Data 1.1: [־ـ $]=$ UPSTEP Rhythm Tone

\begin{tabular}{|l|l|}
\hline $\begin{array}{l}\text { Ai Pengujung mah upami anyar, eta wae, naon } \\
\text { nya. }\end{array}$ & {$\left[\_-\square\right]$} \\
\end{tabular}

In the sample data 1.7 above is the tone intonance of Upstep. In the word " $A i$ Pengujung" the low tone intonation moves higher. Then it becomes high in the word
' $\boldsymbol{m a h}$ ' and slowly the tone returns half lower in the word 'upami' to quickly rise again to the word 'anyar' to drop flat on 'eta' then increase again to the word 'wae' 
Thamrin, \& Isnendes, Sundanese dialect in Sinar Resmi traditional village in Solok district ...

slowly decreasing on the word 'naon nya' So that the flow of the wavy tone is shaped like a porch of a staircase that rises to the top.
Below the general description of data 2 can be seen in Figure 2 below

Data 2 (Abah Amil 69 years old)

No Conversational Dialect Sentence

Form of intonation Rhythm

(DOWNDRIFT, DOWNSTEP, and UPSTEP)

1. Tina SARA teh diperdalem, janten 'ngan benten bahasa, teu digelar teu nembrak. Jadi nyumput buni dinu 'caang,némbrak bari teu 'katingali.

2. Muhun. leuwih kental upami meresapi mayunan pademelan. Saatos shalat drubur mayunan padamelan kakayaan alam, mensyukurina langkung jero. Tiasa kaluar cisoca pami shalat di pinggir wahangan, dina batu
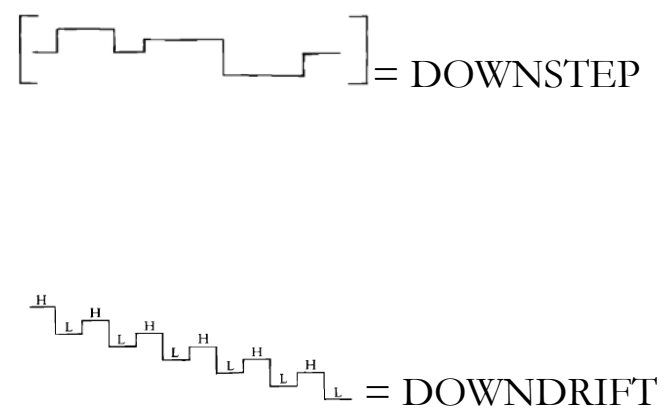

3. He'eh, ningali saatosna urang netepan, pami dikir na di sisi wahangan, caket sawah, wahangan ngalir dina batu, murudul (ngurudut)éta cisoca.

4. Kana ka Agungan Maha Kawasa, sedih kitu. Meresapna téh langkung-langkung kitu.
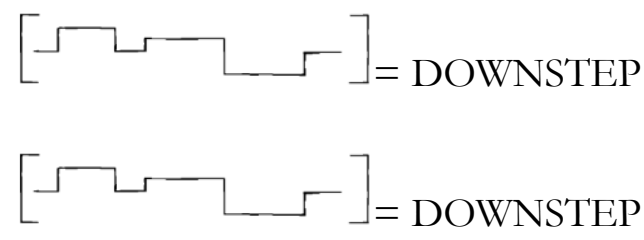

5. Muhun, bener. Sapertos pangan aya éta kedah kieu-kieu, do'a kieu-kieu

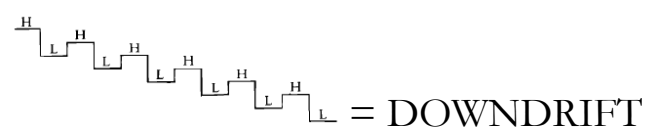

6. Nya samodel kitulah. Panan upami ningali lab ku alam ayeuna. Jadi téh kitu sarolat shalatna mah, tapi...

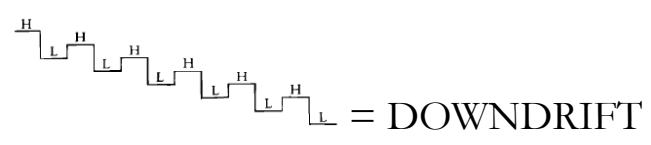

7. Di luar henteu dianggé kitu,

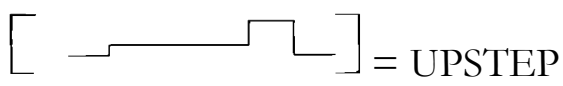

8. Muhun keturunan janteun tiasa turun-temurun, ngobrol-ngobrol sapertos kieu

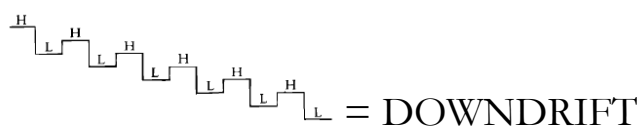

9. Pami kasaluhureun mah adi, sapertos, "di kadieu!', tah kitu

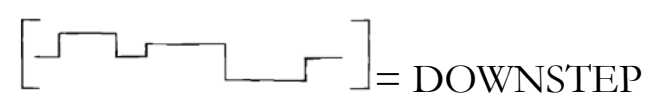

10. Mubun, istri pameget. Atanapi disebat namina ari eta biasana "di kadieu hela" sareng "kaka aya priyogi"

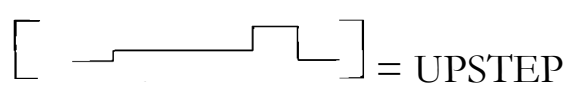

11. Di bumi. $\boldsymbol{A i}$ upami $\boldsymbol{d i}$ ditu mah teu sawios.Eta kalebet pantangan. 
Jurnal Pendidikan Bahasa dan Sastra, Volume 20, Nomor 1, April 2020, pp. 1 - 15

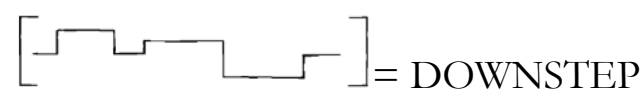

12. Ngan aya di ditu.

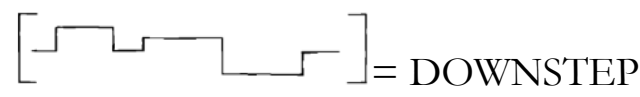

13. Ambu mah husus, eta upami ambu mah titel. Panggilan hormat teh ambu

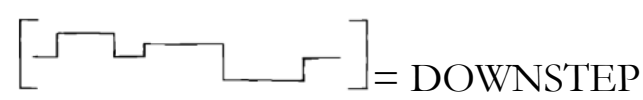

14. Kalangkung eta nu tina pertanian, anu awalna kitu.

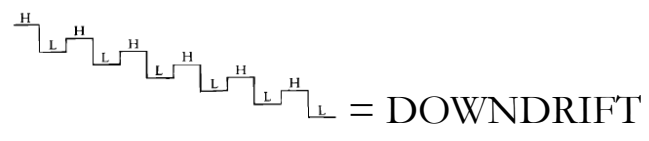

15. Awalna wengi, Padabal eta awalna aya keneh sa teu acan na bade urang kana Pertanian nyarios urang teh, nyarios ka dua belah pihak

16. Upami abdi Kedah nyarios, ka ramana ibu ka ramana abdi, pami tos teu aya rama gentosna rama, nyarios menta du'a restu bade ngawitan pakaya

17. Muhun ka langkung eta, sa teu acan na beraktifitas. Lajeung upami bade melak nyarios deui ka ibu jeung ka rama ka dua belah pibak, menta du'a restu. Lajeung bade ngawitan panen nyarios deui.

18. Sami wae. Sami ka alo

19. disebat Karabat, saderek tebih kitu nya
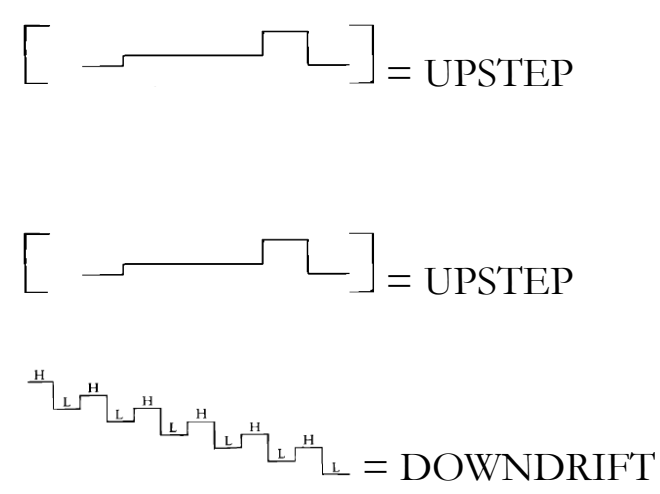

20. Ngan aya di ditu.

21. Muhun muhun. Jadi ulah semarangan. Contona апи пијu hamil, ulah saturutturutna kudu inget ka si utun, kudu inget jabang bayi.

22. Utun teh bayi istri, pami inji mah bayi lakilaki.

23. Pasarna di palabuhan di dieu mah tebih
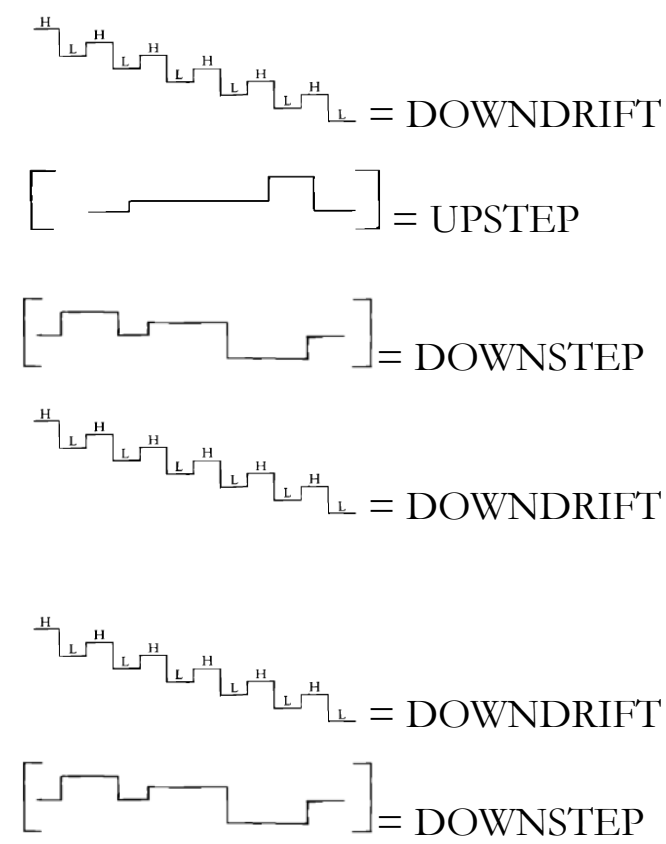

24. Muhun, teu tiasa ngadadak. Paling sa'aya aya lalab kitu wae.

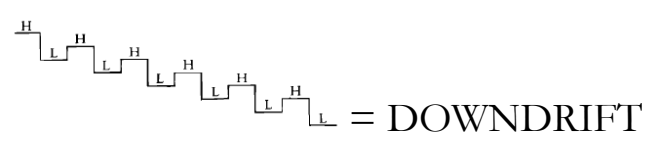

25. Ob kitu.. Seeur pami pantangan mah seeur. Pantangan, Khususna pantangan naon beula kitu tah 
Thamrin, \& Isnendes, Sundanese dialect in Sinar Resmi traditional village in Solok district ...

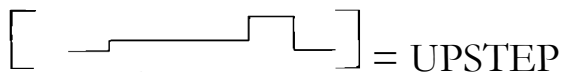

26. Teu kenging ulah kanggo sidkah.

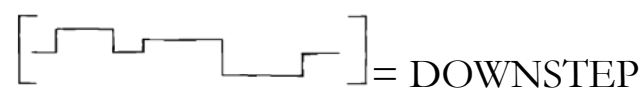

27. Contohna kieu, pami Bapak ieu meser motor, contoh nya ieu. Meser motor, eta teh kedah dirasulan.

28. Kedah disukuran sareng diburipan. Aya kaitan sareng ayam teh, nya, eta kanggo hurip.
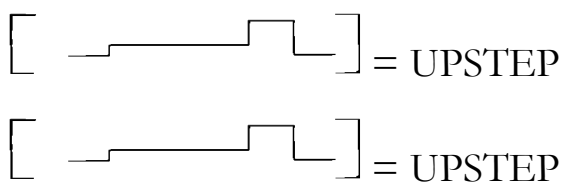

29. Oh seeur. Dina bidang naon kitu pan.

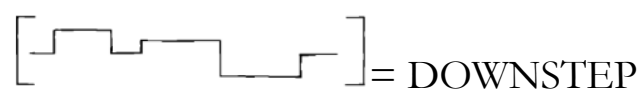

30. Tah, kedah sukuran heula.

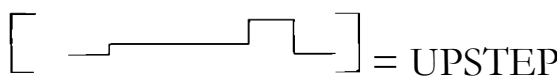

Voice intonation rhythm data 2:
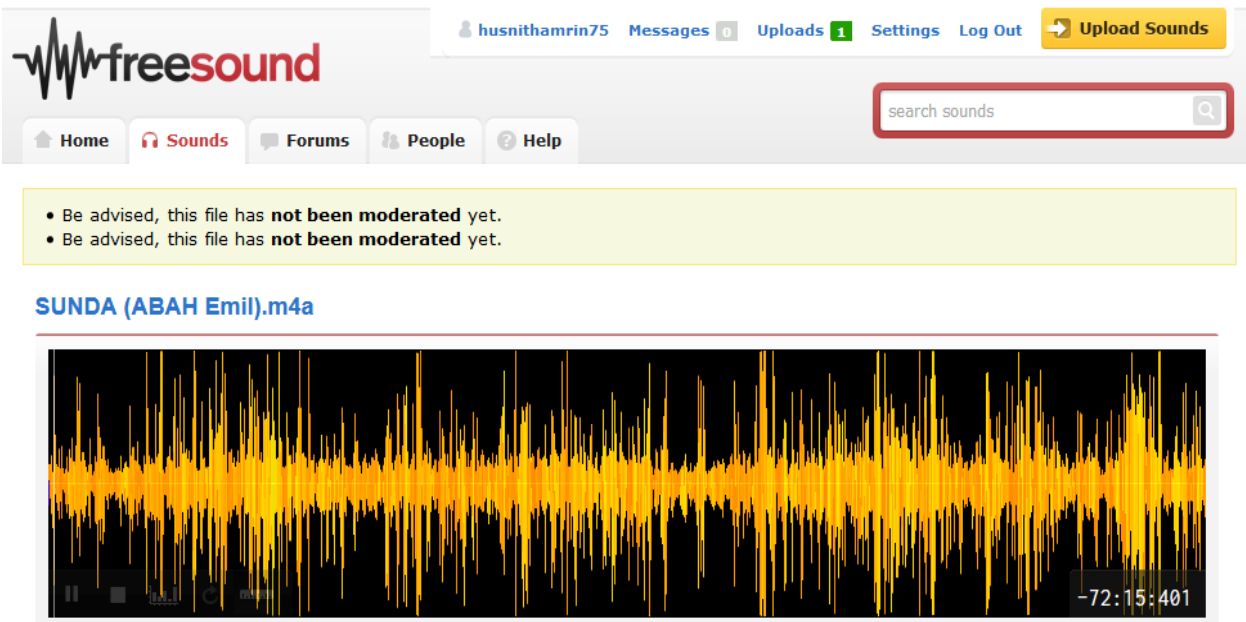

In the second description of the data above, Abah Emil's (69 years) conversation dialect sentence consists of 30 conversation sentences representing parents as elders in Sinar Resmi village indigenous people. The data found three types of categories, namely; 1) DOWNDRIFT intonation tone found 10 types. 2) Intonation of DOWNSTEP tones found 11 types. 3) Intonation of UPSTEP

- Data Analysis 2 (Abah Amil 69 years old)

Data 2.5 :

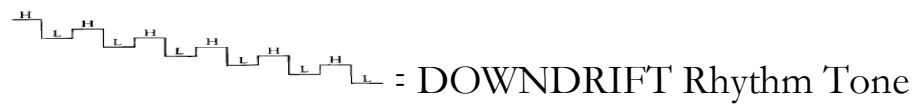

tones found 9 types. It can be seen clearly in the sound intonation wave image that shows the equality of tone intonations that are more likely to start from high then end up in a low tone so that the appearance of tone intonation in each category does not show striking tone in the high level of low intonation. in sequence the type of downstep tone that is significant dominates.

$$
\begin{array}{|l|l|}
\hline \begin{array}{l}
\text { Muhun, bener. Sapertos pangan aya éta kedah } \\
\text { kieu-kieu, do'a kieu-kieu }
\end{array} & \text {. }
\end{array}
$$


In example data 2.5 above is an intonation of downdrift tones. In the word 'Muhun' the tone intonance tone tends to be high, then it slows down a little slowly to pada bener. Food Sapertos "and rises up again to the word 'aya eta', drops lower again to the word 'kedah', rises again on the word 'kieu-kieu' decreases again on the word 'prayer' rising again on the word 'kieukieu'. Thus the intonation tone grooves are shaped like a descending terrace.

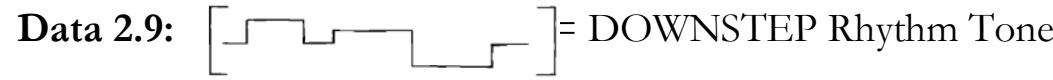

\begin{tabular}{|l|l|l|}
\hline $\begin{array}{l}\text { Pami kasaluhureun mah adi, sapertos, "di } \\
\text { kadieu!", tah kitu }\end{array}$ & DOWNSTEP
\end{tabular}

In the example data 2.9 above is the tone of the downstep tone. In the word 'Pami' the tone is low. Then it is rather slow to go high on the word " kasaluhureun mah" ,and the tone slowly returns low on the words "adi, sapertos" slowly rising again in the word " di kadieu!" Declining again in the word "tah kitu" In the end the tone groove is shaped like a corrugated terrace.

Data 2. 10: $[\longleftarrow \square]=$ Ritme Nada UPSTEP

\begin{tabular}{|l|l|}
\hline $\begin{array}{l}\text { Mubun, istri pameget. Atanapi disebat namina } \\
\text { ari eta biasana "di kadieu hela" sareng "kaka } \\
\text { aya priyogi" }\end{array}$ & {$[-]=U P S T E P$} \\
\hline
\end{tabular}

In the sample data 2.10 above is the tone intonance of Upstep. In the word 'Mubun, istri pameget. Atanapi disebat 'low tone intonation moves higher. Then it becomes high on the word 'namina' and slowly becomes half lower on the word 'ari eta biasana' then rises again to the word 'in kadieu hela' then drops slightly flat on 'sareng "kaka' then rises again to the word 'aya priyogi'. Thus the groove of the wavy tone is shaped like a terrace of stairs which rises to the top.

In this case there are intonation sentence categories which are downdrift, downstep, and upstep (see Katamba 1996). Downdrift: Analysis of data referred to as downdrift tones, which are language tones which tend to rise later rather slowly and become low, such as terracing (see Katamba 1996). Furthermore, the total number of categories of downdrift tone was found to be 12 types of intonation. In other words, both the original form and the after form of the word have different levels of intonation, for example at the beginning of the word high intonation level, then the next word returns the intonation to be low, so that changes in high low intonation result in changes in uptoning intonation. However, when viewed in terms of age, this downdrift intonation is more likely to be dominated by the older age group, this is because they are not contaminated from cultural customs originating from outside they remain silent and stick to local cultural and linguistic customs so that the authenticity of the accent Their native language seems to be clearly evident in the form of defense in accordance with the dialect of the village's traditional village dialect. On the contrary, among young people, there seems to be a tone of downdrift tone that has very little high and low tones that can be heard, so they can often travel and settle outside the traditional village. So that clearly heard the tone of the dialect that is not so thick with the rhythm that rises and 
falls in accordance with the geography of the place they live in the form of mountain valleys which also more or less can affect the daily communication conversation that they do with urban people.

Downstep; the tone of the downstep is the low-pitched situation towards high and automatically and slowly the tone returns low then the tone slowly rises again. Then found the total number of categories of downstep tone tone numbered 21 types of intonation. Of all ages both young and old. This intonation is often found in the description of the dialect of the dialect of the traditional village of Sinar Resmi. This could be that most of the emphasis on articulation lies at the beginning of the conversation sentence. The phoneme form is also more dominant in the form of a consonant which has the potential to affect the high tone intonation located at the beginning of the sentence. Therefore, both young and old, the consonant phoneme articulation at the beginning of the word has a great chance to form a high tone intonation even though there are also several vowel phonemes located at the beginning of the sentence that affect the tone height, but the consonant phoneme dominates the height the tone at the beginning of the conversation sentence in the official community of Sinar Resmi.

Upstep; Intonation of the upstep tone is the opposite of the downstep tone, the moving tone is high so phonetically the tone is slowly higher than the word that preceded it. Next found the total number of categories of tone tone upsteps amounting to 27 types of intonation. There is a significant difference from the tone tone of Upstep among young people and the elderly. In the elderly, the tone intonation is not so dominant compared to the young. For young people, the tone tone of the upstep is very dominating and the main trend of the three data descriptions. When viewed from the phoneme form of conversation sentences in young people, most consonant forms are located at the end of the sentence so that the high tone tone is at the end of the sentence. Another decisive factor could be that their activities are always nomadic, living in a permanent residence in the official village of Sinar Resmi. Sometimes they stay outside the village for a long time and many are affected by dialect variations in the city so that it has a little effect on the authenticity of their dialect as residents of the Sinar Resmi village.

\section{CONCLUSION}

This study explores 2 problems, namely the form of intonance and the influence of intonance on age differences found in the conversational dialect of the Sundanese language in the Sinar Resmi traditional village of Sinar Resmi Village, Cisolok District, Sukabumi District. The data of this study included 60 conversational dialect sentences from two respondents. The overall number of categories of downdrift tone intonation is 12 types of intonation. Then the tone tone of the downstep is 21 intonations. Finally, Upstep tone tone numbered 17. First, it was found the first data with a number of intonations of conversation dialect sentences from Erik (36 years) totaling 30 conversational sentences representing teenagers in the millennial era in the Sinar Resmi village indigenous people. The data found three types of categories, namely; First, the DOWNDRIFT Intonation tone is found in 2 types. Second, the tone of DOWNSTEP found 10 types. Third, the tone of UPSTEP is found in 18 types. In the second data, it was found, Abah Emil's (69) years) conversation dialect sentence consisted of 30 conversational sentences representing parents as elders in Sinar Resmi village indigenous people. The data found three types of categories, namely; 1) DOWNDRIFT intonation tone found 10 types. 2) Intonation of DOWNSTEP tones found 11 types. 3) Intonation of UPSTEP tones found 9 types. From the results of the two respondent data analysis, it can be concluded that there are significant differences in tone tone from the ages and young people. As for one of the factors that influence the existence of dialect differences from young people, namely 
they always travel outside the area so that it influences the dialect intonation of the tone of the conversation. Whereas in the old age they settled and it was almost rare to travel from outside the village so that the dialect of local conversation persisted in its authenticity.

In this research only investigated the tone intonance of conversational as limited to male gender which only compared differences in tone intonance between young and old. It is recommended for the next researcher to do research on the gender of women and all ages, for example children, adolescents, adults, and parents. So that it can be seen the variation of the tone of conversation in full in the traditional village community in Sinar Resmi village as a whole.

\section{REFERENCES}

Ah Jun, S.(2006). Prosodic typology: the phonology of intonation and phrasing. New York: Oxford University Press.

Ayatrohaedi.(1979). Dialektologi sebuah pengantar. Jakarta: Pusat Pembinaan dan Pengembangan Bahasa Departemen Pendidikan dan Kebudayaan.

Arifin, E.Z.(2017). Bahasa sunda dialek priangan. Jurnal Pujangga, 2(1), $p 1$ 41.

Alwi, H, et al.(2003). Tata baku bahasa Indonesia. Jakarta: Balai Pustaka.

Clark, J., \& Collin, Y. (1995). An introduction to phonetics \& phonology. China: Blackwell publisher.

Crystal, D. (1989). The Cambridge encyclopedia of language. Cambridge University.

Chaer, A. (2003). Linguistik umum. Jakarta: Rineka Cipta.

De Lacy, P. (2007). The cambridge handbook of phonology. New York: Cambridge University Press.

Davenport, M., \& Hannahs, S.J. (2005). Introducing phonetics \& phonology. New York: Hodder Arnold.

Gordon, K. M. (2016). Phonological typology. United Kingdom: University: Oxford University.
Gut, U.(2009). Introduction to English phonetics and phonology. Frankfurt: Peter Lang.

Halim, A.(1984). Intonasi dalam bubungannya dengan sintaksis bahasa Indonesia. Jakarta: Djambatan London.

Kamus Besar Bahasa Indonesia (KBBI). (2001). Jakarta: Balai Pustaka.

Kridalaksana, H. (2001a). Fungsi bahasa dan sikeap bahasa. Edisi II, Cet. I. Ende: Nusa Indah. .(2001b). Kamus linguistic. Jakarta: Gramedia.

Kugler, F.(2009). Introduction to variation and radience in phonetics and phonology. Berlin: Walter de Gruyter.

Katamba,F.(1996). An introduction to phonology. London \& New York: Longman.

Lodge, K.(2009).Phonology sameness and difference. Edinburgh: Edinburgh University Press.

McMahon, A.(2016). An introduction to english phonology. Britain: Edinburgh University Press.

Makhtar, R.(2018). Pengaruh dialek Kelantan dalam bahasa temiar: satu analisis fonologi structural. International Journal of Education, Pshycology and Counseling, 3(11), 4254.

Nababan, P.W.J.(1993). Sosiolinguisti: Suatu Pengantar.Jakarta: Pusat Gramedia.

Odden, D.(2005). Introducing phonology. New York: Cambridge University Press.

Parera, J.D. (1994). Morfologi bahasa, Jakarta: Gramedia.

Pateda, M.(1988). Linguistik sebuah pengantar, Bandung: Angkasa

Putrayasa, I.B. (2008). Kajian morfologi (Bentuk derivasional dan infleksional). Bandung: Refika Aditama.

Pennington, M. (2007). Phonology in context. New York: Palgrave Mcmillan.

Ramlan, M. (1997). Morfologi: suatu tinjauan deskriptif. Yogyakarta: C.V. Karyono.

Roach, P. (1998).English phonetics \& phonology. United Kingdom: Cambridge University Press. 
Thamrin, \& Isnendes, Sundanese dialect in Sinar Resmi traditional village in Solok district ...

Samsuri. (1991). Analisis Bahasa. Jakarta: Erlangga.

Waridah. (2015). Penggunaan Bahasa dan Variasi Bahasa dalam Berbahasa dan Berbudaya. Jurnal Simbolika, 16(2), 84-92.
Yule, G. (1986). The Study of language. Melbourne: Cambridge University Press.

Zulaeha, I. (2010). Dialektologi. Yogyakarta: Graha Ilmu. 